\title{
HUBUNGAN ANTARA HARGA DIRI DAN MOTIVASI BERPRESTASI DENGAN PRESTASI BELAJAR FISIKA SISWA SMA
}

\author{
N.K.R.W.Sulastri ${ }^{1}$, N.K.Rapi ${ }^{2}$, D.O.Rachmawati ${ }^{3}$ \\ ${ }^{1,2,3}$ Program Studi Pendidikan Fisika, Universitas Pendidikan Ganesha, Singaraja \\ e-mail: kadek.risma.windi20@undiksha.ac.id, ketut.rapi@undiksha.ac.id, dewioktofa.r@undiksha.ac.id
}

\begin{abstract}
Abstrak
Penelitian ini bertujuan untuk menganalisis hubungan antara harga diri dan motivasi berprestasi dengan prestasi belajar fisika. Penelitian ini berjenis korelasional dengan metode ex-post facto. Populasi penelitian ini adalah seluruh siswa kelas X MIPA SMA Negeri di Kota Semarapura Tahun Pelajaran 2019/2020 yang berjumlah 466 orang. Sampel sebanyak 247 orang dipilih menggunakan teknik proportional random sampling. Data harga diri dan motivasi berprestasi siswa dikumpulkan dengan kuesioner. Data prestasi belajar fisika dikumpulkan dengan tes essay. Nilai reliabilitas kuesioner harga diri, motivasi berprestasi, dan tes prestasi belajar fisika berturut-turut 0,847; 0,875 ; dan 0,892 . Teknik analisis yang digunakan untuk menguji hipotesis adalah analisis regresi linier sederhana dan analisis regresi ganda. Hasil penelitian adalah sebagai berikut: 1) terdapat hubungan positif yang signifikan antara harga diri dan prestasi belajar fisika dengan koefisien korelasi 0,605 dan SE $14,7 \%$; 2) terdapat hubungan positif yang signifikan antara motivasi berprestasi dengan prestasi belajar fisika dengan koefisien korelasi 0,667 dan SE 32,4\%; dan 3) terdapat hubungan positif yang signifikan antara harga diri dan motivasi berprestasi secara simultan dengan prestasi belajar fisika dengan koefisien korelasi 0,686 dan SE 47,1\%.
\end{abstract}

Kata- kata kunci: harga diri, motivasi berprestasi, prestasi belajar fisika

\begin{abstract}
This research aimed at investigating the relationship between self-esteem and achievement motivation with physics learning achievement. This research was correlational research with ex-post facto design. The population of this research was 466 students of grade X MIPA of all SMANs in Semarapura City in academic year of 2019/2020, while the sample of 247 students was chosen by proportional random sampling. Data of physics learning achievement were collected by essay test. The reliability value of the self-esteem questionnaire, achievement motivation, and physics learning achievement test successively were $0.847,0.875$, and 0.892 . The analysis technique used to test the hypothesis was simple linear regression analysis and double regression analysis. The results of the study are as follows: 1) there is a significant positive relationship between self-esteem and physics learning achievement with the correlation coefficient of 0.605 and SE $14.7 \%$,2) there is a significant positive relationship between achievement motivation and physics learning achievement with the correlation coefficient of 0.667 and SE 32.4\%, and 3) there is a significant positive relationship between self-esteem and achievement motivation simultaneously with physics learning achievement with the correlation coefficient of 0.686 and SE $47.1 \%$.
\end{abstract}

Keywords : self-esteem, achievement motivation, physics learning achievement

\section{Pendahuluan}

Sumber daya manusia yang berkualitas, sehingga mampu meningkatkan taraf hidupnya merupakan aset bagi sebuah negara. Pendidikan merupakan sarana untuk mengembangkan potensi dan keterampilan masyarakat. Melalui pendidikan diharapkan dapat menciptakan manusia yang beriman, produktif, kreatif, dan inovatif sehingga mampu bersaing pada era saat ini yang menuntut persaingan ketat. Untuk mewujudkan harapan tersebut diperlukan upaya upaya untuk meningkatkan kualitas pendidikan di Indonesia.

Pendidikan memiliki kaitan yang erat dengan belajar. Belajar sebagai sebuah proses yang terjadi antara guru dan siswa agar terjadinya perubahan struktur kognitif siswa ke arah yang lebih baik. Prestasi belajar merupakan hasil dari sebuah proses belajar, sehingga menjadi salah satu indikator yang menunjukkan kualitas pendidikan. Prestasi belajar dalam arti sempit menunjukkan keberhasilan siswa dalam mencapai indikator pembelajaran. Menurut Suryabrata (2015) prestasi belajar siswa merupakan kemampuan siswa yang diperoleh dari 
proses pembelajaran. Evaluasi dalam proses pembelajaran menjadi sangat penting karena dapat digunakan untuk mendiagnosis kesulitan belajar siswa (Arikunto, 2015). Prestasi belajar diharapkan benar-benar mampu memberikan informasi mengenai keberhasilan belajar siswa secara akurat sehingga mampu mendeskripsikan kualitas pendidikan di Indonesia. Menurut Bloom (dalam Anderson, et al. (2001) terdapat taksonomi yang menunjukkan tingkatan prestasi belajar siswa yang terdiri dari dua ranah yaitu ranah pengetahuan dan proses kognitif. Ranah pengetahuan meliputi faktual, konseptual, prosedural, dan metakognitif. Ranah proses kognitif meliputi mengingat (C1), memahami (C2), mengaplikasikan (C3), menganalisis (4), mengevaluasi (C5), dan menciptakan (C6). Belajar sebagai sebuah proses yang kompleks sehingga prestasi belajar siswa juga dipengaruhi oleh berbagai faktor.

Kenyataan yang muncul di lapangan yaitu kualitas pendidikan di Indonesia masih tergolong rendah. Berdasarkan hasil tes Programme for International Student Assessement (PISA) tahun 2018, Indonesia memperoleh peringkat 70 dari 78 negara pada kompetensi ilmu pengetahuan alam, dengan skor 396 dari skor rata-rata 489 (OECD, 2019). Hasil ini menunjukkan prestasi belajar siswa dalam bidang ilmu pengetahuan alam masih rendah. Ditinjau dalam prestasi belajar fisika, berdasarkan data Kementerian Pendidikan dan Kebudayaan (2019) menyatakan yaitu nilai rata-rata Ujian Nasional (UN) SMA pada mata pelajaran fisika pada Tahun Pelajaran 2018/2019 hanya sebesar 45,78. Nilai rata-rata UN SMA fisika di Provinsi Bali sebesar 48,06. Sedangkan nilai UN fisika siswa SMA di Kabupaten Klungkung sebesar 42,95. Hal ini menggambarkan prestasi belajar siswa khususnya pada mata pelajaran fisika masih rendah.

Prestasi belajar yang rendah ini menimbulkan adanya kesenjangan antara kenyataan yang muncul di lapangan dengan harapan pemerintah. Siswa sebagai pebelajar yang secara aktif mengkonstruksi pengetahuannya sehingga prestasi belajar siswa dipengaruhi oleh faktor dalam diri siswa. Hal ini diperkuat oleh Wahdania, et al. (2017) yang menyatakan upaya peningkatan pencapaian prestasi belajar siswa diperlukan pengoptimalan faktor-faktor dalam diri siswa yang memengaruhi pembelajaran. Faktor afektif dan psikologis yang ada dalam diri siswa memainkan peran penting dalam keberhasilan belajar siswa (Asakereh \& Yousofi, 2018).

Harga diri (self-esteem) merupakan perasaan berharga dalam diri individu yang muncul karena adanya penilaian positif dan negatif seseorang terhadap dirinya sendiri. Adanya rasa berharga ini membuat siswa tidak malu untuk berargumen dalam diskusi kelas dan mau bertanya ketika mengalami kesulitan belajar. Hal ini membuat siswa memperoleh prestasi belajar lebih tinggi. Sebaliknya siswa yang memiliki harga diri rendah cenderung menjadi pasif di sekolah. Hal ini dikarenakan siswa bersikap pesimis yang menimbulkan rasa takut bertanya dengan guru ketika ada materi yang kurang dimengerti.

Harga diri (self-esteem) dipandang sebagai evaluasi afektif individu berupa perbedaan antara citra diri yang realistis dengan diri ideal yang diharapkannya (Lawrence, 2006). Harga diri (self-esteem) merupakan kemampuan individu menilai dirinya sehingga dapat membantu mereka mempelajari diri sendiri dan berinteraksi dengan orang lain (Mruk, 2006). Harga diri membuat siswa merasa berharga sehingga ia memandang dirinya mampu menghadapi kesulitan dalam belajar fisika. Astika (2019) mendefinisikan harga diri (self-esteem) sebagai kemampuan seseorang untuk menilai dirinya sendiri dalam menyelesaikan masalah kehidupan. Coopersmith (dalam Mruk, 2006) menyatakan terdapat empat dimensi harga diri (self-esteem) yaitu: keberartian diri (significance), kekuatan diri (power), kompetensi (competence), dan ketaatan diri (virtue).

Penelitian Malhotra, Sharma, Ajanta, dan Bala (2019) menyatakan bahwa harga diri turut berperan dalam menentukan prestasi belajar siswa dengan koefisien korelasi sebesar 0,632. Penelitian Asakereh dan Yousofi (2018) memberikan informasi bahwa harga diri merupakan prediktor terkuat di antara efikasi diri dan berpikir reflektif terhadap prestasi belajar siswa. Penelitian Astika (2019) memperlihatkan adanya hubungan positif dan signifikan antara harga diri dan efikasi diri dengan prestasi belajar fisika dengan koefisien korelasi sebesar 0,356 dan sumbangan efektif 11,48\%. Mindrawan (2015) memberikan hasil penelitian terdapat hubungan antara harga diri dengan prestasi belajar IPA dengan korelasi 0,381 dan 
sumbangan efektif $14,50 \%$. Oleh karena itu, harga diri dikatakan memiliki hubungan yang positif dengan prestasi belajar siswa.

Motivasi berprestasi merupakan upaya yang mendorong seseorang untuk meraih prestasi setinggi mungkin. Motivasi berprestasi berperan dalam kegiatan pembelajaran untuk membuat siswa berusaha meningkatkan prestasinya. Siswa dengan motivasi berprestasi tinggi akan menunjukkan sikap sikap seperti terlibat aktif dalam pembelajaran, produktif, berambisi, dan tekun dalam pembelajaran. Sebaliknya, siswa yang memiliki motivasi berprestasi rendah cenderung tidak memiliki inisiatif untuk belajar dan pasif dalam pembelajaran. Oleh karena itu, motivasi berprestasi memiliki hubungan yang positif dengan prestasi belajar siswa.

Hakikat motivasi dalam pembelajaran adalah dorongan internal yang berupa hasrat untuk berhasil, maupun dorongan eksternal yang berupa penghargaan yang ditujukan pada siswa agar terjadi perubahan perilaku (Uno, 2008). Motivasi berprestasi adalah dorongan dalam diri individu untuk meraih prestasi dalam kegiatan pembelajaran. Menurut Surya dan Husna (2018) motivasi mendorong siswa berkompetisi sehingga meningkatkan prestasi belajar siswa tersebut. Menurut Samiati, Kadir, Bey, dan Rahim (2019) belajar sangat memerlukan adanya motivasi berprestasi agar hasilnya lebih optimal. Motivasi berprestasi merupakan upaya yang mendorong seseorang menjadi lebih baik dengan melakukan aktivitas dengan standar keunggulan, sehingga mampu meraih prestasi yang diinginkan secara maksimal (Mc.Clelland dalam Heckhausen, 1967).Terdapat dua dimensi motivasi berprestasi berdasarkan Achievement Motivation Inventory (Bergmann, 2015) yaitu self-assurance dan ambition.

Penelitian-penelitian berikut mendukung adanya hubungan antara motivasi berprestasi dengan prestasi belajar. Sivrikaya (2019) menyatakan bahwa terdapat hubungan positif antara motivasi dengan prestasi belajar dengan korelasi 0,151. Dewi (2019) menyatakan terdapat korelasi antara motivasi berprestasi dengan hasil belajar sebesar 0,573. Tastan (2018) menyebutkan korelasi antara motivasi akademik dengan prestasi belajar sebesar 0,677. Nurani, et al., (2018) menyatakan bahwa adanya hubungan antara motivasi berprestasi dengan prestasi belajar dengan koefisien korelasi 0,525 dan sumbangan efektif 27,6\%. Surya dan Husna (2018) menyatakan adanya hubungan yang positif dan signifikan antara motivasi berprestasi dengan hasil belajar dengan koefisien korelasi 0,909. Wahdania (2017) menyatakan korelasi antara efikasi diri, harga diri, dan motivasi dengan hasil belajar matematika sebesar 0,865. Trisnowali (2017) dalam penelitiannya memperoleh kontribusi motivasi berprestasi, minat belajar, dan sikap secara simultan sebesar 0,702. Penelitian Azizah (2019) menunjukkan adanya hubungan yang positif dan signifikan antara motivasi berprestasi dan prestasi belajar fisika siswa kelas X MIPA di Kota Tabanan dengan korelasi 0,59 dan sumbangan efektif $24 \%$.

Berdasarkan penelitian-penelitian terdahulu disimpulkan bahwa harga diri dan motivasi berprestasi memiliki hubungan yang positif dengan prestasi belajar. Prestasi belajar fisika yang tinggi dapat dicapai dengan memperhatikan faktor dalam diri siswa seperti harga diri dan motivasi berprestasi.

Adapun tujuan penelitian ini yaitu:

1) Mendeskripsikan hubungan antara harga diri dan prestasi belajar fisika siswa kelas $X$ MIPA SMA Negeri di Kota Semarapura Tahun Pelajaran 2019/2020.

2) Mendeskripsikan hubungan antara motivasi berprestasi dan prestasi belajar fisika siswa kelas X MIPA SMA Negeri di Kota Semarapura Tahun Pelajaran 2019/2020.

3) Mendeskripsikan hubungan harga diri dan motivasi berprestasi secara simultan dengan prestasi belajar fisika siswa kelas X MIPA SMA Negeri di Kota Semarapura Tahun Pelajaran 2019/2020.

\section{Metode}

Penelitian ini adalah penelitian korelasional dengan metode ex post-facto. Penelitian ini menganalisis hubungan antarvariabel tapa memberikan perlakuan. Hubungan antara setiap variabel dapat dilihat seperti Gambar 1. 


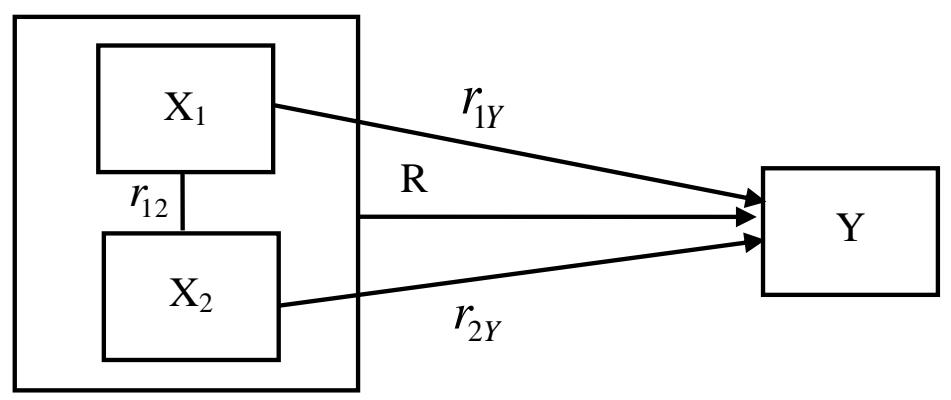

\section{Gambar 1 Hubungan antarvariabel Penelitian}

Populasi dalam penelitian ini adalah seluruh siswa kelas X MIPA SMA Negeri di Kota Semarapura Tahun Pelajaran 2019/2020 yang berjumlah 466 orang. Sampel dipilih menggunakan teknik proportional random sampling. Jumlah sampel yang digunakan dalam penelitian ini yaitu sebanyak 247 orang. Data harga diri dan motivasi berprestasi siswa diambil dengan menggunakan kuesioner dengan skala Likert, sedangkan data prestasi belajar fisika diambil dengan menggunakan tes uraian dengan materi Dinamika Partikel dan Hukum Newton tentang Gravitasi.

Uji coba instrumen kuesioner harga diri dan motivasi berprestasi yang dilakukan terdiri dari uji validitas isi, uji konsistensi internal butir, dan uji reliabilitas kuesioner. Hasil uji coba masing-masing instrumen kuesioner diperoleh nilai reliabilitas kuesioner harga diri sebesar 0,847 dan nilai reliabilitas kuesioner motivasi berprestasi sebesar 0,875 . Uji coba tes prestasi belajar fisika meliputi uji validitas isi, uji konsistensi internal butir, indeks kesukaran butir, indeks daya beda butir, dan uji reliabilitas tes. Nilai reliabilitas tes prestasi belajar fisika sebesar 0,892. Berdasarkan hasil uji reliabilitas, seluruh instrumen memiliki reliabilitas dengan kategori sangat tinggi (Sugiyono, 2010), sehingga dinyatakan sebagai instrumen yang bersifat reliabel.

Uji asumsi sebagai uji prasyarat yang harus dipenuhi, sehingga dilakukan sebelum melakukan uji hipotesis. Uji asumsi yang dilakukan dalam penelitian ini meliputi: uji normalitas sebaran data, uji linieritas dan keberartian arah regresi, uji autokorelasi, uji multikolinieritas, dan uji heterokedastisitas. Uji asumsi menggunakan bantuan SPSS 23 for Windows. Hasil uji asumsi diperoleh bahwa seluruh data telah memenuhi semua uji asumsi sehingga dapat dilakukan uji hipotesis.

Pengujian hipotesis menggunakan teknik analisis korelasi product moment. Analisis regresi linier sederhana digunakan untuk menguji hipotesis pertama dan kedua serta analisis regresi ganda dua prediktor digunakan untuk menguji hipotesis ketiga. Uji hipotesis yang dilakukan menggunakan bantuan aplikasi SPSS 23 for Windows dan Microsoft Office Excel 2007.

Hipotesis dalam penelitian ini antara lain sebagai berikut.

1) Terdapat hubungan positif antara harga diri dan prestasi belajar fisika siswa kelas X MIPA SMA Negeri di Kota Semarapura Tahun Pelajaran 2019/2020.

2) Terdapat hubungan positif antara motivasi berprestasi dan prestasi belajar fisika siswa kelas X MIPA SMA Negeri di Kota Semarapura Tahun Pelajaran 2019/2020.

3) Terdapat hubungan positif antara harga diri dan motivasi berprestasi secara simultan dengan prestasi belajar fisika siswa kelas X MIPA SMA Negeri di Kota Semarapura Tahun Pelajaran 2019/2020.

\section{Hasil dan Pembahasan}

Deskripsi umum variabel harga diri, motivasi berprestasi, dan prestasi belajar fisika terdiri dari skor rata-rata dan simpangan baku. Deskripsi ketiga variabel tersebut disajikan pada Tabel 1. 
Tabel 1. Deskripsi Harga Diri, Motivasi Berprestasi, dan Prestasi Belajar Fisika

\begin{tabular}{lccc}
\hline \multicolumn{1}{c}{ Statistik } & $\begin{array}{c}\text { Skor Harga } \\
\text { Diri }\end{array}$ & $\begin{array}{c}\text { Skor Motivasi } \\
\text { Berprestasi }\end{array}$ & $\begin{array}{c}\text { Skor Prestasi } \\
\text { Belajar Fisika }\end{array}$ \\
\hline Skor rata-rata & 130,4 & 129,9 & 43,8 \\
Simpangan baku & 11,362 & 12,688 & 11,602
\end{tabular}

Tabel 1 menunjukkan bahwa: a) harga diri berada pada kategori tinggi dengan skor rata-rata 130,4 dan simpangan baku 11,362 ; b) motivasi berprestasi berada pada kategori sedang dengan skor rata-rata 129,9 dan simpangan baku 12,688; dan 3) prestasi belajar fisika berada pada kategori rendah dengan skor rata-rata 43,8 dan simpangan baku 11,602.

Skor harga diri siswa ditinjau berdasarkan distribusi frekuensi pada pedoman nilai absolut skala lima. Hasil konversi disajikan pada Tabel 2.

Tabel 2. Distribusi Frekuensi Harga Diri

\begin{tabular}{llc}
\hline \multicolumn{1}{c}{ Kriteria } & \multicolumn{1}{c}{ Kategori } & $\begin{array}{c}\text { Jumlah Siswa } \\
\boldsymbol{f}_{\boldsymbol{0}}\end{array}$ \\
\hline $\mathrm{X} \geq 156$ & Sangat tinggi & 4 \\
$130 \leq \mathrm{X}, 156$ & Tinggi & 126 \\
$104 \leq \mathrm{X}<130$ & Sedang & 116 \\
$78 \leq \mathrm{X}<104$ & Rendah & 1 \\
$\mathrm{X}<78$ & Sangat rendah & 0 \\
& \multicolumn{2}{c}{ Total } \\
\hline
\end{tabular}

Tabel 2 menunjukkan bahwa skor harga diri terbanyak berada pada kategori tinggi yaitu sebesar 126 siswa dengan persentase $51,01 \%$. Terdapat 4 siswa $(1,62 \%)$ yang memiliki harga diri dengan kategori sangat tinggi, 116 siswa (46,96\%) dengan harga diri sedang, 1 siswa $(0,41 \%)$ memiliki harga diri rendah, dan tidak ada siswa yang memiliki harga diri sangat rendah. Secara umum skor rata-rata harga diri siswa kelas X MIPA SMA Negeri di Kota Semarapura berada pada kategori tinggi.

Harga diri dapat ditinjau berdasarkan skor rata-rata yang diperoleh pada setiap dimensi untuk memberikan informasi yang lebih mendetail terkait tingkat harga diri siswa. Skor rata-rata harga diri siswa pada masing-masing dimensi dapat disajikan pada Tabel 3.

\section{Tabel 3. Skor Rata-Rata Setiap Dimensi Harga Diri}

\begin{tabular}{lc}
\hline Dimensi Harga Diri & Skor Rata-Rata \\
\hline Power & 127,5 \\
Significance & 132,2 \\
Virtue & 136,4 \\
Competence & 128,1 \\
\hline
\end{tabular}

Berdasarkan Tabel 3 terlihat bahwa harga diri siswa dengan kategori sedang berada pada dimensi power (kekuatan diri) dan competence (kompetensi). Sedangkan dimensi significance (keberartian diri) dan virtue (ketaatan individu) berada pada kategori tinggi. Skor rata-rata harga diri tertinggi pada dimensi virtue. Hal ini menunjukkan bahwa siswa mampu menaati peraturan di sekolah maupun di rumah sehingga siswa dijadikan panutan dalam lingkungannya. Hal ini dapat meningkatkan harga diri siswa. Sedangkan dimensi terendah harga diri yaitu power. Hal ini menunjukkan bahwa siswa masih belum memiliki kekuatan diri sehingga cenderung mengikuti pendapat orang lain.

Skor motivasi berprestasi siswa dapat ditinjau berdasarkan distribusi frekuensi pada pedoman konversi nilai absolut skala lima. Hasil konversi disajikan pada Tabel 4. 
Tabel 4 Distribusi Frekuensi Motivasi Berprestasi

\begin{tabular}{llc}
\multicolumn{1}{c}{ Kriteria } & \multicolumn{1}{c}{ Kategori } & $\begin{array}{c}\text { Jumlah Siswa } \\
\boldsymbol{f}_{0}\end{array}$ \\
\hline$X \geq 160$ & Sangat tinggi & 0 \\
$133 \leq X<160$ & Tinggi & 101 \\
$107 \leq X<133$ & Sedang & 136 \\
$80 \leq X<107$ & Rendah & 10 \\
$X<80$ & Sangat rendah & 0 \\
& \multicolumn{2}{c}{ Total } \\
\hline
\end{tabular}

Pada Tabel 4 terlihat bahwa skor motivasi berprestasi dengan jumlah terbanyak berada pada kategori sedang yang berjumlah 136 orang dengan persentase 55,06\%. Terdapat 101 siswa yang memiliki motivasi berprestasi tinggi, 10 siswa dengan motivasi berprestasi rendah, dan tidak ada siswa yang memiliki motivasi berprestasi sangat tinggi maupun sangat rendah. Secara keseluruhan skor rata- rata motivasi berprestasi siswa berada pada kategori sedang.

Motivasi berprestasi ditinjau berdasarkan skor rata-rata yang diperoleh siswa pada setiap dimensi untuk memberikan informasi yang lebih detail terkait tingkat motivasi berprestasi siswa. Skor rata-rata motivasi berprestasi siswa pada setiap dimensi disajikan pada Tabel 5.

Tabel 5 Skor Rata-Rata Setiap Dimensi Motivasi Berprestasi

\begin{tabular}{lc}
\hline Dimensi Motivasi Berprestasi & Skor Rata-Rata \\
\hline Self-assurance (kemandirian) & 126,7 \\
Ambition (kemauan) & 133,1 \\
\hline
\end{tabular}

Tabel 5 menunjukkan bahwa skor motivasi berprestasi siswa pada dimensi self-assurance sebesar 126,7 dengan kualifikasi sedang. Sedangkan pada dimensi ambition sebesar 133,1 dengan kualifikasi tinggi. Hal ini menunjukkan bahwa siswa terlihat lebih mandiri dalam belajar daripada memiliki kemauan untuk memperoleh prestasi sehingga memunculkan adanya motivasi berprestasi.

Skor tes prestasi belajar fisika siswa juga dapat ditinjau berdasarkan distribusi frekuensi pada pedoman Penilaian Acuan Patokan (PAP). Hasil konversi dapat disajikan pada Tabel 6 berikut ini.

Tabel 6 Distribusi Frekuensi Prestasi Belajar Fisika

\begin{tabular}{llc}
\multicolumn{1}{c}{ Kriteria } & \multicolumn{1}{c}{ Kategori } & $\begin{array}{c}\text { Jumlah Siswa } \\
\boldsymbol{f}_{0}\end{array}$ \\
\hline $91-100$ & Sangat tinggi & 0 \\
$83-90$ & Tinggi & 0 \\
$75-82$ & Sedang & 0 \\
$40-74$ & Rendah & 160 \\
$0-39$ & Sangat rendah & 87 \\
& & Total \\
\hline
\end{tabular}

Tabel 6 memperlihatkan skor tes prestasi belajar fisika siswa dengan jumlah terbanyak pada kategori rendah sebesar 160 siswa atau 64,78\%. Terdapat 87 siswa $(35,22 \%)$ yang memperoleh skor tes prestasi belajar fisika sangat rendah serta tidak ada siswa yang memperoleh skor tes prestasi belajar fisika pada kategori sangat tinggi, tinggi, dan sedang. Secara umum, skor tes prestasi belajar fisika siswa kelas X MIPA SMA Negeri di Kota Semarapura berada pada kategori yang rendah sehingga perlu adanya usaha untuk meningkatkan prestasi belajar tersebut. 
Prestasi belajar fisika dapat ditinjau berdasarkan skor rata-rata pada setiap dimensi untuk memberikan informasi yang lebih mendetail terkait tingkat prestasi belajar fisika siswa kelas $\mathrm{X}$ MIPA SMA Negeri di Kota Semarapura. Skor rata-rata prestasi belajar fisika siswa pada masing-masing dimensi disajikan pada Tabel 4.9.

Tabel 7 Skor Rata-Rata dan Kualifikasi Prestasi Belajar Fisika pada Setiap Dimensi

\begin{tabular}{llc}
\hline & Dimensi & Skor Rata-Rata \\
\hline Pengetahuan & Konseptual & 43,8 \\
Proses kognitif & Menganalisis & 47,5 \\
& Mengevaluasi & 9,8 \\
\hline
\end{tabular}

Berdasarkan Tabel 7 diketahui bahwa skor rata-rata tes prestasi belajar fisika pada dimensi pengetahuan konseptual sebesar 43,8 yang tergolong pada kualifikasi rendah. Sedangkan skor rata-rata prestasi belajar siswa pada dimensi proses kognitif menganalisis sebesar 47,5 yang tergolong kualifikasi rendah dan pada dimensi proses kognitif mengevaluasi sebesar 9,8 yang tergolong kualifikasi sangat rendah.

Uji hipotesis yang digunakan yaitu analisis regresi linier sederhana untuk menguji hipotesis pertama dan kedua, sedangkan analisis regresi ganda dua prediktor digunakan untuk menguji hipotesis ketiga. Secara umum ringkasan hasil pengujian hipotesis yaitu sebagai berikut.

Tabel 7 Ringkasan Hasil Uji Hipotesis

\begin{tabular}{|c|c|c|c|c|c|c|c|}
\hline Variabel & Persamaan Regresi & $F_{h}$ & $F_{t}$ & $\mathbf{r}$ & $\mathbf{R}^{2}$ & $\begin{array}{c}K \\
(\%)\end{array}$ & $\begin{array}{l}\text { SE } \\
(\%)\end{array}$ \\
\hline $\begin{array}{l}\mathrm{X}_{1} \\
\text { dengan } \\
\mathrm{Y}\end{array}$ & $\hat{Y}=-46,021+0,589 X_{1}$ & $\begin{array}{l}141 \\
592\end{array}$ & 3,89 & 0,605 & 0,366 & $\begin{array}{l}36,6 \\
\%\end{array}$ & $14,7 \%$ \\
\hline $\begin{array}{l}\mathrm{X}_{2} \\
\text { dengan } \\
\mathrm{Y}\end{array}$ & $\hat{Y}=-44,628+0,581 X_{2}$ & $\begin{array}{l}195 \\
957\end{array}$ & 3,89 & 0,667 & 0,444 & $\begin{array}{l}44,4 \\
\%\end{array}$ & $32,4 \%$ \\
\hline $\begin{array}{l}X_{1} \text { dan } \\
X_{2} \\
\text { dengan } \\
Y\end{array}$ & $\hat{Y}=-55,364+0,237 X_{1}+0,423 X_{2}$ & $\begin{array}{l}108 \\
475\end{array}$ & 3,04 & 0,686 & 0,471 & $\begin{array}{l}47,1 \\
\%\end{array}$ & $47,1 \%$ \\
\hline
\end{tabular}

Hipotesis pertama menyatakan "terdapat hubungan antara harga diri dan prestasi belajar fisika siswa kelas X MIPA SMA Negeri di Kota Semarapura Tahun Pelajaran 2019/2020". Nilai $F_{\text {hitung }}$ pada uji hipotesis pertama sebesar 141,592 , sedangkan nilai $F_{\text {tabel }}$ sebesar 3,89 , sehingga $\mathrm{F}_{\text {hitung }}>\mathrm{F}_{\text {tabel. }}$. Maka $\mathrm{H}_{\mathrm{o}}$ ditolak dan Ha diterima. Jadi dapat disimpulkan bahwa terdapat hubungan positif dan signifikan antara harga diri dan prestasi belajar fisika siswa kelas X MIPA SMA Negeri di Kota Semarapura.

Nilai koefisien korelasi antara harga diri dan prestasi belajar fisika sebesar 0,605 dan sumbangan efektif harga diri terhadap prestasi belajar fisika yaitu sebesar $14,7 \%$. Sisanya yaitu $85,3 \%$ merupakan jumlah total pengaruh variabel lain terhadap prestasi belajar fisika. Hasil penelitian terdahulu juga menunjukkan nilai sumbangan efektif harga diri yang kecil. Mindrawan (2015) menunjukkan pengaruh harga diri terhadap prestasi belajar IPA di Kecamatan Nusa Penida dengan sumbangan efektif sebesar 11,66\%. Astika (2019) mengungkapkan sumbangan efektif self-esteem terhadap prestasi belajar fisika siswa kelas $\mathrm{X}$ MIPA SMA Negeri di Kota Amlapura sebesar 11,48\%. Sumbangan efektif penelitian ini berbeda dengan hasil penelitian sebelumnya karena adanya perbedaan tempat penelitian dan karakteristik siswa yang diteliti. 
Persamaan regresi harga diri dan prestasi belajar fisika yaitu :

$\hat{Y}=-46,021+0,589 X_{1}$

$\mathrm{Hal}$ ini menunjukkan bahwa setiap pertambahan nilai harga diri $\left(X_{1}\right)$ sebesar satu satuan maka prestasi belajar fisika (Y) akan bertambah sebesar 0,589 satuan.

Hasil penelitian-penelitian terdahulu juga sesuai dengan hasil penelitian ini. Malhotra, et al,. (2019) menyebutkan variabel harga diri memberikan pengaruh yang positif terhadap prestasi belajar siswa dengan besar koefisien korelasi harga diri dengan prestasi adalah 0,632; Wahdania, et al., (2017) menyebutkan terdapat hubungan positif dan signifikan antara efikasi diri, harga diri, dan motivasi terhadap hasil belajar siswa dengan kontribusi sebesar 74,8\%; Kucukibis (2019); Bhagat (2016); Astika (2019) dan Mindrawan (2015) dalam penelitiannya juga menunjukkan adanya hubungan yang positif antara harga diri dan prestasi belajar siswa.

Hipotesis kedua menyatakan "terdapat hubungan positif antara motivasi berprestasi dan prestasi belajar fisika siswa kelas X MIPA SMA Negeri di Kota Semarapura". Hasil uji F sebesar 195,957 dan nilai $F_{\text {tabel }}$ sebesar 3,89, maka $F_{\text {hitung }}>F_{\text {tabel }}$ sehingga Ho ditolak dan Ha diterima. Jadi dapat disimpulkan bahwa terdapat hubungan positif dan signifikan antara motivasi berprestasi dan prestasi belajar fisika siswa kelas X MIPA SMA Negeri di Kota Semarapura.

Koefisien korelasi antara motivasi berprestasi dan prestasi belajar fisika sebesar 0,667. Sumbangan efektif prediktor terhadap kriterium sebesar $32,4 \%$. Hasil ini memberikan kesimpulan bahwa motivasi berprestasi berpengaruh cukup besar terhadap prestasi belajar siswa di Kota Semarapura. Hasil penelitian terdahulu juga memberikan hasil sumbangan efektif motivasi berprestasi yang cukup besar. Dewi, et al., (2019) menunjukkan sumbangan efektif motivasi berprestasi terhadap prestasi belajar sebesar 27\%. Nurani, et al., (2018) menyatakan sumbangan efektif yang diberikan oleh motivasi berprestasi terhadap prestasi belajar yaitu 27,6\%. Penelitian Azizah (2019) menginformasikan sumbangan efektif motivasi berprestasi terhadap prestasi belajar fisika sebesar $24 \%$. Perbedaan besar sumbangan efektif penelitian-penelitian sebelumnya dengan hasil penelitian ini disebabkan oleh perbedaan tempat penelitian dan karakteristik siswa yang diteliti.

Persamaan regresi motivasi berprestasi dengan prestasi belajar fisika yaitu :

$\hat{Y}=-44,628+0,581 X_{2}$

Hal ini berarti setiap kenaikan satu satuan motivasi berprestasi maka prestasi belajar fisika meningkat sebesar 0,581 satuan.

Hasil penelitian- penelitian terdahulu juga mendukung hasil penelitian ini. Dewi, et al., (2019) memberikan hasil yaitu terdapat hubungan positif dan signifikan antara motivasi berprestasi dengan hasil belajar siswa dengan koefisien korelasi 0,573; Srivikaya (2019) dalam penelitiannya diperoleh hasil yaitu antara motivasi dengan prestasi belajar terdapat korelasi sebesar 0,151; Surya dan Husna (2018) memberikan hasil adanya hubungan yang positif dan signifikan antara motivasi berprestasi dengan hasil belajar dengan koefisien korelasi 0,909; Nurani, et al., (2018) memberikan hasil bahwa kepercayaan diri dan motivasi berprestasi memiliki hubungan positif dan signifikan terhadap prestasi belajar siswa dengan korelasi 0,525 ; Azizah (2019); Tastan, et al., (2018); dan Trisnowali (2017) juga memberikan hasil penelitian bahwa adanya hubungan positif antara motivasi berprestasi dan prestasi belajar siswa.

Hipotesis ketiga menyatakan terdapat hubungan positif antara harga diri dan motivasi berprestasi dengan prestasi belajar fisika siswa kelas X MIPA SMA Negeri di Kota Semarapura Tahun Pelajaran 2019/2020. Nilai $F_{\text {hitung }}$ yang diperoleh sebesar 108,475 dan $\mathrm{F}_{\text {tabel }}$ didapatkan sebesar 3,04, maka $\mathrm{F}_{\text {hitung }}>\mathrm{F}_{\text {tabel }}$ sehingga $\mathrm{H}_{\mathrm{o}}$ ditolak dan Ha diterima. Besar koefisien korelasi harga diri dan motivasi berprestasi terhadap prestasi belajar fisika yaitu 0,686 .

Nilai koefisien kontribusi harga diri dan motivasi berprestasi terhadap prestasi belajar fisika sebesar $47,1 \%$. Hal ini memberikan informasi bahwa pengaruh variabel harga diri dan motivasi berprestasi terhadap prestasi belajar fisika sebesar $47,1 \%$, sedangkan $52,9 \%$ lainnya dipengaruhi oleh variabel lain namun tidak diteliti dalam penelitian ini. 
Persamaan regresi ganda yang diperoleh yaitu :

$\hat{Y}=-55,364+0,237 X_{1}+0,423 X_{2}$

$\mathrm{Hal}$ ini menunjukkan bahwa koefisien regresi variabel harga diri dan motivasi berprestasi bernilai positif, sehingga jika nilai kedua variabel semakin tinggi maka nilai prestasi belajar fisika juga semakin tinggi. Setiap kenaikan prediktor masing- masing satu satuan, maka kriterium akan meningkat sebesar 0,66 satuan.

Prestasi belajar dipengaruhi oleh komponen lain, terutama dalam diri siswa sebagai subyek belajar (Sardiman, 2006). Menurut Suryabrata (2015) faktor internal seperti aspek fisiologis dan psikologis berpengaruh pada prestasi belajar siswa. Clemed dan Bean (dalam Asakereh, 2018) menyatakan bahwa siswa yang memiliki harga diri rendah cenderung memunculkan rasa ketidakpuasan dalam belajar sehingga memengaruhi proses belajarnya. Siswa yang memiliki motivasi berprestasi tinggi ditunjukkan dengan sikap optimis dan aktif dalam kegiatan pembelajaran (Sivrikaya, 2019).

Berdasarkan hasil pengujian semua hipotesis tersebut, diperoleh bahwa seluruh $\mathrm{H}_{\circ}$ ditolak dan Ha diterima. Sehingga dapat disimpulkan bahwa terdapat hubungan positif antara harga diri dan motivasi berprestasi, baik secara individual maupun bersama-sama terhadap prestasi belajar fisika. Semakin tinggi harga diri dan motivasi berprestasi, maka prestasi belajar fisika siswa juga akan semakin tinggi. Dalam pembelajaran fisika, siswa sering dihadapkan pada persoalan yang menuntut pemahaman konsep dan kemampuan matematis. Siswa yang memiliki harga diri yang tinggi akan menghargai dirinya bahwa ia sedang berada dalam proses pembelajaran sehingga ia akan berusaha meningkatkan prestasinya meskipun kerap menemukan kegagalan. Siswa yang memiliki motivasi berprestasi tinggi akan tekun belajar dan sering latihan soal karena ia memiliki target untuk mencapai taraf prestasi yang diinginkan. Dengan demikian prestasi belajar siswa juga akan meningkat. Oleh karena itu, harga diri dan motivasi berprestasi memiliki hubungan positif dengan prestasi belajar fisika siswa.

Penelitian ini juga memberikan temuan bahwa skor rata-rata harga diri siswa berada pada kategori tinggi, skor rata-rata motivasi berprestasi siswa berada pada kategori sedang, dan skor rata-rata prestasi belajar fisika berada pada kategori rendah. Namun jika skor harga diri maupun motivasi berprestasi semakin tinggi maka skor tes prestasi belajarnya juga semakin tinggi. Hasil ini juga menunjukkan adanya pengaruh variabel lain terhadap prestasi belajar fisika namun tidak diteliti dalam penelitian ini. Hal ini dibuktikan dari nilai sumbangan efektif variabel harga diri dan motivasi berprestasi sebesar $47,1 \%$. Sisanya $52,9 \%$ adalah pengaruh variabel lain.

Penelitian ini juga dipengaruhi oleh berbagai faktor di lapangan seperti: 1) kurangnya kejujuran siswa dalam mengisi kuesioner sehingga hasilnya kurang akurat; 2) tes yang diberikan secara online dengan waktu yang terbatas sehingga beberapa siswa kekurangan waktu untuk menjawab tes; dan 3) adanya pengaruh faktor lain seperti materi yang diujikan belum benar- benar dipahami siswa dengan baik karena sistem pembelajaran yang berlangsung secara online; 4) anggapan beberapa siswa bahwa hasil kuesioner dan tes ini tidak mempengaruhi nilai mereka di sekolah sehingga mereka kurang termotivasi untuk menjawab.

\section{Simpulan dan Saran}

Berdasarkan uraian pembahasan di atas maka dapat disimpulkan beberapa hal yaitu sebagai berikut.

1. Terdapat hubungan positif antara harga diri dan prestasi belajar fisika siswa kelas X MIPA SMA Negeri di Kota Semarapura Tahun Pelajaran 2019/2020.

2. Terdapat hubungan positif antara motivasi berprestasi dan prestasi belajar fisika siswa kelas X MIPA SMA Negeri di Kota Semarapura Tahun Pelajaran 2019/2020.

3. Terdapat hubungan positif antara harga diri dan motivasi berprestasi terhadap prestasi belajar fisika siswa kelas X MIPA SMA Negeri di Kota Semarapura Tahun Pelajaran 2019/2020. 
Adapun beberapa saran yang disampaikan sebagai tindak lanjut dari hasil penelitian ini yaitu sebagai berikut.

1. Untuk guru fisika sebagai tenaga pendidik yang berpartisipasi langsung dalam proses pembelajaran di kelas dengan siswa maka guru dapat merencanakan pembelajaran yang dapat menumbuhkan harga diri dan motivasi berprestasi siswa sehingga siswa dapat meningkatkan prestasi belajarnya. Guru dapat merancang pembelajaran secara berkelompok yang bersifat heterogen sehingga antarsiswa dapat saling mengisi dan menumbuhkan rasa saling menghargai antarsiswa. Guru juga dapat mengembangkan motivasi berprestasi siswa melalui pemberian reinforcement berupa nilai tambahan dan penghargaan lainnya sehingga siswa lebih termotivasi untuk belajar.

2. Untuk pemerintah khususnya instansi terkait bidang pendidikan agar hendaknya memperhatikan faktor internal siswa dalam penyusunan kurikulum sehingga prestasi belajar yang dapat dicapai siswa secara maksimal.

3. Untuk penelitian selanjutnya agar meneliti variabel psikologis lainnya yang turut berpengaruh terhadap prestasi belajar fisika siswa, sehingga prestasi belajar fisika dapat lebih ditingkatkan.

\section{Daftar Pustaka}

Anderson, L. W., (2001). A taxonomy for learning, teaching, and assessing (Edisi Pertama). New York: Addison Wesley Longman.

Arikunto, S. (2015). Dasar-dasar evaluasi pendidikan (Edisi Kedua). Jakarta: Bumi Aksara.

Asakereh, A., \& Yousofi, N. (2018). Reflective thinking, self-efficacy, self-esteem, and academic achievement of Iranian EFL students. International Journal of Educational Psychology. 7(1), 68-89. doi:10.17583/ijep.2018.2896.

Astika, I.W.M. (2019). Hubungan self-efficacy dan self-esteem dengan prestasi belajar fisika siswa kelas X MIPA SMA Negeri di Kota Amlapura. Skripsi (tidak diterbitkan). Jurusan Pendidikan Fisika, Fakultas Matematika dan IImu Pengetahuan Alam, Universitas Pendidikan Ganesha.

Azizah, N. (2019). Hubungan motivasi berprestasi dan sikap sosial dengan prestasi belajar fisika siswa kelas X MIPA SMA Negeri di Kota Tabanan. Skripsi (tidak diterbitkan). Jurusan Pendidikan Fisika, Fakultas Matematika dan IImu Pengetahuan Alam, Universitas Pendidikan Ganesha.

Bergmann, S. (2015). Achievement motivation inventory (AMI). Oxford: Hogrefe.

Bhagat, P. (2016). Relationship between self-esteem and academic achievement of secondary school students. International Journal of Innovative Research and Development. 5(7), 211-216. E-ISSN 2278 - 0211.

Dewi, K.M.S., Suwatra, I.G.N., \& Suarjana, M. (2019). Kontribusi disiplin belajar dan motivasi berprestasi terhadap hasil belajar matematika. Journal for Lesson and Learning Studies. 2(1), 121-130. e-ISSN : 2615-7330.

Heckhausen, H. (1967). The anatomy of achievement motivation. Germany: Academic Pers.

Kementerian Pendidikan dan Kebudayaan. (2019). Nilai ujian nasional program studi IPA Tahun Pelajaran 2018/2019. Diakses pada 3 Juni 2019 dari https://puspendik.kemdikbud.go.id/hasil-un/.

Kucukibis, H. F., \& M. Gul. (2019). The relationship between attitudes towards physical activity and self-esteem of high school students. Asian Journal of Education and Training, 5(1), 70-78. doi: 10.20448/journal.522.2019. 51.70.73.

Lawrence, D. (2006). Enhancing self-esteem in the classroom (Edisi Ketiga). London: Paul Chapman Publishing.

Malhotra, A., Sharma, A., Ajanta, \& Bala, S. (2019). Study the relationship between academic achievement and self-esteem of senior secondary school students. J. Evid Based Med. Healthc. 6(11), 899-903. doi:10.18410/jebmh/2019/189.

Mindrawan, I W. (2015). Pengaruh efikasi diri dan harga diri terhadap prestasi belajar IPA siswa kelas VIII SMP Negeri se-Kecamatan Nusa Penida Tahun Pelajaran 2014/2015. 
Skripsi (tidak diterbitkan). Jurusan Pendidikan Fisika, Fakultas Matematika dan IImu Pengetahuan Alam, Universitas Pendidikan Ganesha.

Mruk, C. J. (2006). Self-esteem research, theory, and practice (Edisi Ketiga). New York: Springer Publishing Company.

Nurani, Sunarto, \& Wardani, K.D. (2018). Pengaruh kepercayaan diri dan motivasi berprestasi terhadap prestasi belajar peserta didik pada mata pelajaran ekonomi di SMA Negeri 8 Surakarta. BISE: Jurnal Pendidikan Bisnis dan Ekonomi. 4(1), 1-13. e-ISSN: 2548-7175.

OECD. (2019). PISA 2018 insight and interpretation. Artikel Online. Tersedia pada https://www.oecd.org/pisa/PISA\%202018\%20Insights\%20and\%20 Interpretations\%20FINAL\%20PDF.pdf.

Sardiman, A.M. (2006). Interaksi dan motivasi belajar mengajar (Edisi Pertama). Jakarta: PT. Raja Grafindo Persada.

Sivrikaya, A.H. (2019). The Relationship between academic motivation and academic achievement of the students. Asian Journal of Education and Training. 5(2), 309-315. doi:10.20118/journal.522.2019.52.309.315.

Suastra, I.W. (2017). Pembelajaran sains terkini: mendekatkan siswa dengan lingkungan alamiah dan sosial budayanya (Edisi Pertama). Singaraja: Universitas Pendidikan Ganesha.

Sugiyono. (2010). Metode penelitian pendidikan: pendekatan kuantitatif, kualitatif, dan R\&D (Edisi Kesepuluh). Bandung: Penerbit Alfabeta.

Surya, E., \& Husna, A. (2018). Hubungan sense of humor, kecerdasan emosional, dan motivasi berprestasi terhadap hasil belajar matematika siswa kelas X SMK Teladan Kota Batam. Phytagoras. 7(1), 68-77. E-ISSN : 2615-7926

Suryabrata, S. (2015). Psikologi pendidikan (Edisi Kelima). Jakarta: PT. Raja Grafindo Persada.

Tastan, S.B., Davoudi, S.M.M., Masalimova, A.R., Bersanov, A.S., Kurbanov, R.A., Boiarchuk, A.V., \& Pavlushin, A.A. (2018). The impact of teacher's efficacy and motivation on student's academic achievement in science education among secondary and high school students. EURASIA Journal of Mathematics, Science and Technology Education. 14(6). https://doi.org/10.29333/ejmste/89579.

Trisnowali, A.M.S. (2017). Pengaruh motivasi berprestasi, minat belajar matematika, dan sikap belajar matematika terhadap hasil belajar matematika pada siswa SMA N 2 Watampone. MaPan: Jurnal Matematika dan Pembelajaran. 5(2). doi: https://doi.org/10.24252/mapan. v5n2a8.

Uno, H.B. (2008). Teori motivasi dan pengukurannya (Edisi Pertama). Jakarta: PT. Bumi Aksara.

Wahdania., Rahman, U., \& Sulasteri, S. (2017). Pengaruh efikasi diri, harga diri, dan motivasi terhadap hasil belajar matematika peserta didik kelas X SMA Negeri 1 Bulupoddo Kab. Sinjai. Jurnal Matematika dan Pembelajaran. 5(1), 68-81. E-ISSN:2581-172X. 